\title{
THE SPREAD OF NUCLEAR WEAPONS IN THE MIDDLE EAST: "MORE MAY BE BETTER"?'
}

\author{
Amena Yassine*
}

\begin{abstract}
Resumo
O texto The Spread of Nuclear Weapons in the Middle East: "more may be better"? discute a tese amplamente difundida, segundo a qual a estabilidade política do Oriente Médio depende de uma "nuclear deterrence". Aqui o argumento principal é o oposto: no mundo unipolar atual, quanto mais armas nucleares, menos estabilidade naquela região. $\mathrm{O}$ artigo procura avaliar a problemática da instabilidade no Oriente Médio por meio da ótica da teoria construtivista, segundo Wendt. A tese é a de que a estabilidade no Oriente Médio depende de uma melhoria do conhecimento intersubjetivo, uma vez que os dilemas de segurança são mutáveis ao longo do tempo.
\end{abstract}

Palavras Chave: Retrocesso Nuclear; Conhecimento Intersubjetivo; Oriente Médio; Estabilidade; Segurança Regional;

\begin{abstract}
The present paper assesses the post-Cold War debate on whether the spread of nuclear weapons is either central or peripheral to stability in the Middle East. The argument here is that in the current unipolar structure the spread of such weapons is a major destabilising force in the Middle East. Nuclear deterrence is no guarantee of stability to the region. As security dilemmas are mutable overtime, this paper argues that a condition precedent to stability in the Middle East is a refinement of intersubjective knowledge.
\end{abstract}

Key-words: Nuclear Deterrence. Intersubjective Knowlodge. Middle East. Stability. Regional Security.

Finding the sources of systemic stability ${ }^{2}$ has been one of the major drives underpinning the study of International Relations. As far as some troubled regions such as the Middle East are concerned, the unravelling of threads leading to (sub)systemic stability becomes a pressing matter. That nuclear weapons account for one of these sources is generally agreed by deterrence theorists. Waltz, in a rather ambiguous position, argues however that systemic peacefulness and the endurance of states are results of the nature of the international system ${ }^{3}$ and that "nuclear weapons cannot by themselves be used to explain the stability - or the instability - of the international system"." As long as the international system remains bipolar, he estimates, the spread of nuclear weapons will have minor effects

\footnotetext{
${ }^{1}$ Trabalho apresentado para o seminário de Segurança Internacional com o Professor Barry Buzan, na London School of Economics and Political Science, em Londres, Reino Unido, 2006.

${ }^{2}$ Stability is here understood as either the absence of war between states, or their endurance as political organisations or the equilibrium of forces between them

${ }^{3}$ Cf. Waltz (1979), chapters four and five.

${ }^{4}$ Waltz: 1964, pp. 886.
} 
either at the global or regional level, their spread being actually better ${ }^{5}$. The question stemming from these theories is whether in the post-Cold War system the spread of nuclear weapons is either central or peripheral to (sub)systemic stability. The main argument here is that in the current unipolar structure the spread of such weapons, particularly in the case of the Middle East, is indeed a major destabilising force. Agreeing with Waltz's general premise that structures have independent effect in the course of international outcomes, the first section of this essay will assess new trends in current macro structure that made nuclear weapons a central force influencing international/regional stability. This essay lines up however with Wendt's assumption that agency determines structure and vice-versa ${ }^{6}$ and takes the via media in arguing that a condition precedent to nuclear stability in the Middle East is a refinement of the intersubjective knowledge ${ }^{7}$ the Arab, Persian, Turkish and Jewish countries have built between them since the aftermath of the Second World War. The further subdivision will thus examine this Middle Eastern prevailing ideational structure and suggest alternative paths for nuclear stability in the region.

\section{Nuclear Weapons in the Middle East: “more may be better"?}

As long as current international structure is focused on the containment of Weapons of Mass Destruction (WMD), the more nuclear weapons in the Middle East, the worse, the more destabilising. If in Waltz's time WMD did not count as the highest priority of American governments ${ }^{8}$, in the $21^{\text {st }}$ century that is no longer the case. A quick scan through official statements of major states and international organisations evidences how priorities have been reordered in present times ${ }^{9}$. It is undisputable that the US establishment of terrorism as the nation's major foe and the containment of weapons of mass destruction as the nation's prime task has far-reaching implications to any Muslim country's ambitions of acquiring nuclear weapons ${ }^{10}$. The major of them is that in the current international structure, shaped by the American hegemony, there is no room for the spread of nuclear weapons or WMD of any kind in the Middle East, as the Iraqi ${ }^{11}$ war and the Iranian imbroglio suggest. The second, a

\footnotetext{
5 Note that in "The Spread of Nuclear Weapons: More may be Better" (1981) Waltz concedes that nuclear weapons may be destabilising in that they "change the relations of nations", whatever relations he implies. In analysing however the relationship between the US and the USSR and India, Britain, France and China, he concludes that the spread of nuclear weapons has ambivalent results and that interaction between "new" nuclear weapon states and former ones will be marked by continuities more than by changes. Cf., op. cit., Waltz: 1981, pp.7-10.

${ }^{6}$ Cf. Wendt, 1999.

${ }^{7}$ See also, Wendt, 1992.

${ }^{8}$ Op. cit., Waltz: 1981 , pp.8.

9 On this matter see, for instance, The 2003 European Security Strategy (http://ue.eu.int/cms3 fo/showPage.asp?id=261\&lang=en\&mode=g, accessed on February 27, 2006); "NATO expands presence in Afghanistan"( http://www.nato.int/docu/update/2004/06-june/e0629a.htm, NATO press release, accessed on February 27, 2006); and G8 Gleneagles' Summit statements on The Middle East Peace Process,Iraq, andCounterTerrorism(http://www.g8.gov.uk/servlet/Front?pagename=OpenMarket/Xcelerate/Sho wPage\&c=Page\&cid $=1119518698846$, accessed on February 28, 2006).

10 "The gravest danger our Nation [the United States] faces lies at the crossroads of radicalism and technology. Our enemies have openly declared that they are seeking weapons of mass destruction, and evidence indicates that they are doing so with determination." Cf. The 2002 National Security Strategy of the United States of America, <http://www.whitehouse.gov/nsc/nss.html>, accessed on March 2, 2006, pp. 3-4.

${ }^{11}$ Although the reasons that led to the American invasion of Iraq are contested, this essay considers the official American position that the impetus for a war stemmed from the threat that Saddam Hussein might have weapons of mass destruction. In later December, however, President Bush acknowledged that the intelligence
} 
consequence of the previous, is that Middle Eastern rivalries may exacerbate as a result of the dualist approach (with us or against us) of the US foreign policy - that seems to be what Halliday implies when he comments that " $t \mathrm{t}]$ he Arab world is now divided, between reluctant allies of the US and an enraged population, in a way that was never the case before." 12 Indeed the strength of Waltz's argument for the spread of nuclear weapons seems to have fallen into decline along with the demise of the USSR and the bipolar structure.

Besides the correlation between nuclear weapons and stability, as proposed by theorists of nuclear deterrence ${ }^{13}$, is amorphous or at best ambivalent. No satisfactory conclusions have been drawn as to whether the spread of nuclear weapons has been a stabilising force to the Middle East. To the extent that Israel has endured for almost four decades, despite the unanimous Arab call for its annihilation, the Israeli policy of nuclear ambiguity may be generally regarded as successful. Considering that the Israeli nuclear programme was developed amidst hostile circumstances (Nasser's pan-Arabism), Israeli nuclear deterrence has received much credit for improving Israel's fighting capability and deterring an all-out Arab attack ${ }^{14}$. The efficiency of Israeli nuclear deterrence is nevertheless far from consensual. Maoz (2003) challenges what he calls the "conventional wisdom" that the Israeli nuclear deterrence has protected Israel from any catastrophic war. He argues that no all-out war has been staged against Israel due to the Arab lack of wherewithal or organisational ability rather than to the Israeli non-conventional weaponry. In exploring the three occasions when the Israeli nuclear deterrence was put to test, Maoz concludes that there is no evidence to suggest that Arab states adopted more limited and careful calculations in their offensive against Israel as a result of its nuclear policy. In the May-June 1967 crisis, despite suspicions of Israeli nuclear build up, some fuelled by satellite imagery, Nasser seemed little daunted when he breached all of the casus belli settled in the aftermath of the 1956 Sinai War and allowed for Egyptian troop movements to escalate ${ }^{15}$. In the 1973 Egyptian-Syrian attack, the arming of Israeli nuclear warheads neither prevented the Egyptian massive attacks to recover the Mitla and Gidi Passes nor did it deter the Syrians from firing missiles at Israel. Saddam Hussein, in the 1990s, felt no constraint in both threatening Israel with chemical weapons and launching Scud missiles against it ${ }^{16}$. For Maoz,

that led to the invasion was proved to be wrong. That suggests though an acknowledgment of failure rather than a change in the a priori impetus. Cf., BBC News, <http://edition.cnn.com/2005/POLITICS/12/14/bush.iraq/>, accessed on March 2, 2006.

${ }^{12}$ Cf., Halliday, 2004, pp.8.

${ }^{13}$ Underlying any arguments for nuclear dissemination is the assumption that nuclear weapons inevitably decrease occurrences of war because (i) nuclear states calculate their military strategies and define their national interests more cautiously and (ii) human costs are so high that war escalation is thwarted. To these reasons, Waltz adds other: "a country with a [nuclear] deterrent strategy does not need the extent of territory required by a country relying on conventional defence in depth", which, he concludes, "removes a major cause of war." Op. cit., Waltz: 1981 , pp. 5-6.

${ }^{14}$ On the perspectives expected from the Israeli policy of nuclear ambiguity, see Dowty,1978. See also Maoz, 2003.

15 Op. cit., Maoz, 2003.

${ }^{16}$ See also the correspondence between Zeev Maoz and Louis René Beres to the editor of the International Security journal, Vol. 29, No. 1 (Summer 2004). Whether Iraqi missiles carried no chemical weapons was due to the Iraqi incipient military technology or to containment is unknown - what is certain is that Israel had no missile defence. 
what granted Israeli security (stability) was a rather conventional strategy: "the land-forpeace formula"17.

Further the Arab experience with weapons of mass destruction casts doubts upon the confidence in a common rationality on which proponents of a nuclear deterrence to the Middle East rely. Egypt equipped its army with chemical weapons to fight Israel, then suspected of possessing nuclear weapons, and was reported to have supplied Syria with chemical weapons during the Yom Kippur $\mathrm{War}^{18}$. The lack of caution and regard for human costs was also evidenced by Saddam Hussein, when the dictator seemed to have considered the use of chemical and biological weapons in the 1990-91 Gulf War in an event of a British, American or Israeli nuclear attack, as former British Prime Minister Edward Heath's testimony to the US Congress on December 1990 suggests $^{19}$. Saddam's use of nerve agent in the 1980-88 Iran-Iraq War, which killed 5,000 Iranians and hundreds of Iraq's own Kurdish population $^{20}$ also casts doubts upon the proposition that nuclear weapons are unlikely to be used regionally or at home ${ }^{21}$.

While the efficacy of nuclear weapons as a stabilising force is contested, its ability of bringing instability is less disputed. The acquisition of nuclear weapons by Israel and the attempt to develop them by Iraq is often said to underlie Egypt's and Iran's quest for a nuclear arsenal ${ }^{22}$. Bowen and Kidd remember that Iraq's pursuit of unconventional weapons, their deployment in the conflict and the launching of Scud missiles against Tehran may have been one cause of Iran's major nuclear drive ${ }^{23}$. Any conclusion however suggesting that the wiping out of nuclear weapons from the Middle East would bring the awaited stability to the region should be understood as hasty. Nuclear weapons only account for part of the region's numerous sources of instabilities and the denuclearisation of the Middle East is contingent on overcoming these sources, as the next section shall examine.

\section{Paving the way for nuclear stability in the Middle East:}

The post-Second World War ideational structure prevailing in the Middle East fits well in Wendt's concept of Hobbesian culture ${ }^{24}$. The process of creating intersubjective knowledge between the Arab, Persian and Jewish states has been marked by, as Buzan and Waever (2003) remember, "competition for leadership of the Arab world and interpretations of Arabism, as well as more traditional rivalries over territory, water, and ideology, not to mention clan interests, and issues of royal succession. ${ }^{25}$ " Their religious and ethnic identities are defined by hostile representations of the other: Israelis/Arabs, Sunnis/Shi'ites,

\footnotetext{
17 "The roots of the peace process before and after the 1973 war are found in Israeli policy toward these [Gaza Strip, Golan Heights, Sinai Peninsula and West Bank] territories, rather than in the effect of Israel's nuclear program on the Arab states." Op. cit., Maoz: 2003, pp. 67.

${ }^{18}$ Nasser had previously showed no constraint in using mustard bombs in the 1963-1967 Yemen War. Egypt was also reported to have helped the Iraqi government in the production of its chemical arsenal. Cf. "Chemical Weapons Program", source Global Security webpage <http://www.globalsecurity.org/wmd/world/egypt/cw.htm>, accessed on March 3, 2006.

${ }^{19}$ Cf. "Iraq's use of Chemical Weapons", source Voice of America, March 9, 1998, in Global Security webpage <http://www.globalsecurity.org/wmd/library/news/iraq/1998/980310-iraq.htm>, accessed on March 3, 2006.

${ }^{20}$ Ibidem.

${ }^{21}$ Op. cit., Waltz: 1981, pp. 11-12.

${ }^{22}$ On the Middle East nuclear race, see Maoz, 2003; Bowen and Kidd, 2004; and Taremi, 2005.

${ }^{23}$ Op. cit., Bowen and Kidd: 2004, pp. 263.

${ }^{24}$ Op. cit., Wendt: 1999, chapter 6.

${ }^{25}$ Cf., Buzan and Weaver: 2003, pp. 190.
} 
Persians/Arabs, Muslims/Jews. These enemy dyads reject one another's right to exist independently. Self-help, imminent war, competitiveness, zero-sum game and security dilemmas are the major features of the Middle Eastern Hobbesian culture. Hence Egypt supports coups against the Jordanian monarchy, uses WMD against the Yemeni, embarks on a war against Israel; Syria finances Hamas and strives to maintain influence over Lebanese affairs; Iraq stages a war against Iran, annexes Kuwait, throws chemical weapons against its own Kurdish population; and currently Iran promises to wipe Israel off the map, fosters rivalries within Iraq between Shi'a and Sunnis, and cultivates hegemonic ambitions over the region. As one can sense from Louis Beres tone ${ }^{26}$ Middle Eastern states tend to assume the worst about each other's intensions ${ }^{27}$. This conclusion is in line with some arguments that the Middle East was thrown into the Westphalian system but its members "play a different game". Such idea underlies Solingen's contention that the Middle East needs to "internationalise" 28 .

Contrary to the preaching of some International Relations practitioners such as Lustick, for the above process to take place, the Middle East needs no great power. Neither has the rise of Egypt nor of Iraq nor of Iran come without cost to "internationalisation". Besides proponents of these arguments often seem to hide a tone of pan-Arab or pan-Islamist nostalgia. There can be order under anarchy and the principle of sovereignty allows for this. In Wendt's parlance, sovereignty is a shared knowledge, an institution that evinces the existence of culture between the actors, the recognition of the other's right to exist ${ }^{29}$. Sovereignty epitomises the transition from a Hobbesian culture to a Lockean culture, in which, despite the absence of a central authority, states tend to settle their divergences through peaceful means ${ }^{30}$. For the pessimistic who may be quick to raise the flag of "idealism" or "naivety" against the proposition that building confidence amongst Middle Eastern countries precedes any prospects for security stability in the region, a glance at the European history and the development of relations between Germany and France or the latter and England suffice.

Solingen's essay on the Middle East denuclearisation ${ }^{31}$ draws on the mutability of security dilemmas over time. In assessing the potential lessons the Middle Eastern leaders may learn from the Southern Cone's experience with denuclearisation, she explores how the Argentine-Brazilian experience allowed the two countries to phase out their nuclear ambitions and to fully commit themselves to a bi-lateral nuclear verification agreement under the safeguards of a regional agency (The Agency for Accounting and Control of Nuclear Materials- $\mathrm{ABACC} \mathrm{AC}^{32}$ ) and later of the International Atomic Energy Agency - a process that allowed them to eventually join the Non-Proliferation Treaty (the NPT). That the democratisation of the two countries was instrumental to their cooperation in the nuclear field is undeniable; however, there is insufficient evidence to suggest that democratisation should be taken as a criterion to the process of confidence-building in the Middle East ${ }^{33}$. As this

\footnotetext{
${ }^{26}$ Op. cit., correspondence between Zeev Maoz and Louis René Beres to the editor of the International Security journal, Vol. 29, No. 1 (Summer 2004).

${ }^{27}$ On the Hobbesian logic of anarchy, see, op. cit., Wendt: 1999, chapter 6 and Wendt, 1992.

28 Although by "internationalise" this essay understands a process of assimilation of international laws and costumes rather than of conformity to liberal principles.

${ }^{29}$ Sovereignty is not and must not be confused with ability to influence.

${ }^{30}$ That only means that violence is less likely, rather than non-existent.

${ }^{31}$ Op. cit., Solingen, 2003.

${ }^{32}$ Acronym in Portuguese.

${ }^{33}$ On the debate about the Democratic Peace, see: op. cit., Bruce, 1995; and Layne, 1994.
} 
debate goes beyond the scope set out, suffice it to say that although Sadat's coming to power may have facilitated the Egyptian-Israeli rapprochement, which allowed for the country's unilateral signature of the NPT ${ }^{34}$, Egypt can hardly be regarded as a democracy. However ominous the future of the Middle East may look for some, as for Halliday (2004), who predicts the US and Saudi Arabia's defeat in a post-Saddam world, the American policy for the region need not be seen as a zero-sum game. Signs of improvement may not be afar on the horizon and may be noticed in Iran's backing the new Afghani constitution and supporting President Kharzai; Syria's withdrawal of 3000 troops from Lebanon with prospects for further removal; Turkey's alliance with Israel and improvements in relations between Turkey and both Iran and Syria; Israel's withdrawal from Gaza; and, Egypt's further improvements of its relations with Israel ${ }^{35}$. To that should be added Libya's yielding its nuclear ambitions.

\section{Conclusion:}

The arguments set out lead to the major conclusion that under the $21^{\text {st }}$ century American hegemony the spread of nuclear weapons may be a destabilising force in the Middle East. The dualist tone of the American foreign policy with regard to the war on terrorism and the containment of WMD leave no room for nuclear ambitions in the region. Waltz's case for the proliferation of nuclear weapons thus sounds anachronistic in the unipolar order. As the essay demonstrates that the responses of state actors in the Middle East to the spread of WMD in the region did not display the rationality that theorists of nuclear deterrence predict would be the case, the second conclusion drawn is that the correlation between stability and nuclear weapons is vague. The paper showed that, although Israel's endurance as state may be partly regarded as a result of Israeli nuclear deterrence, unsatisfactory evidence exists to attest the efficiency of such a policy. The rather conventional strategy of "the land-for-peace" gives a more clarifying picture of the relative stability between Israel and its Arab neighbours. The third conclusion being then that while the stabilising potential of nuclear weapons is contested, its destabilising capability is less in dispute. Far from advocating that denuclearisation would be the panacea to the Middle Eastern Pandora's box, this essay holds that the denuclearisation of the Middle East is contingent on a process of building confidence between the Arab, Jewish, Persian, Turkish states, similar mutatis mutandis to the one undergone by the Southern Cone. Drawing on the constructivist view that identities, cultures, and security dilemmas are mutable over time, this essay espouses that the Middle Eastern countries need no great power but a reformulation of the categories that define their representation of one another.

\section{Bibliography:}

\footnotetext{
${ }^{34}$ Note that some arguments go, as in Beres, 2004, that Egypt's signature of the NPT, its claim for a Nuclear Free Zone in the Middle East, and the very peace process are part of a plot to weaken Israel "to the point where it can no longer defend itself", pp. 176. Such arguments, as Maoz, 2004 notes, have no scientific or foundational basis and rather seem contradiction in terms: by giving up its nuclear weapons and recognising Israel's right to exist, Egypt seems to be in a weaker relative position towards Israel rather than the other way round. The argument only suggests that indeed as in Wendt's model of Hobbesian culture, of one another's intentions in the Middle East the worse is expected.

${ }^{35}$ Cf. Holli, 2005.
} 
Beres, Louis R. and Maoz, Zeev (2004), 'Israel and the Bomb', International Security, 29:1, pp. 175-180.

Bowen, Wyn Q. and Kidd, Joanna (2004), 'The Iranian Nuclear Challenge', International Affairs, 80:2, pp. 257-76.

Russet, Bruce (Spring, 1995), "The Democratic Peace", International Security, 19:4, pp. 164-184.

Buzan, Barry and Wæver, Ole (2003), Regions and Powers: The Structure of International Security, Cambridge: CUP.

Dowty, A. (1978), 'Non-proliferation: the Israeli Case', International Studies Quarterly, $21: 1$.

Halliday, Fred (2004) 'American and Arabia after Saddam', Open Democracy, http://www.opendemocracy.net/debates/article-2-95-1900.jsp

Hollis, R (2005), "The greater Middle East”, in 2005 SIPRI Year Book, Oxford: OUP.

Layne, C. (Autumn, 1994), "Kant or Cant: The Myth of the Democratic Peace", International Security, 19:2, pp. 5-49

Lustick, Ian S. (1997), 'The Absence of Middle Eastern Great Powers: Political "Backwardness" in Historical Perspective', International Organization, 51:4, pp. 653-83.

Solingen, Etel(2001), 'Middle East denuclearisation? Lessons from Latin America's Southern Cone', Review of International Studies, 27:3, pp. 375-94.

Taremi, Kamran, (2005) 'Beyond the Axis of Evil: Ballistic Missiles in Iran's Military Thinking', Security Dialogue 36:1, pp. 93-108.

Waltz, Kenneth N. (1964) "The Stability of a Bipolar World”, Daedalus, 93:3, pp. 881-909. (1970) Theory of International Politics, Reading, MA.

(1981) "The Spread of Nuclear Weapons: More may be Better", Adelphi

171, London, IISS.

Wendt, Alexander (1999), Social Theory of International Politics. Cambridge: CUP.

( Spring, 1992),"Anarchy is what states make of it: the social construction

of power politics", International Organization, 46: 2, pp. 391-425. 